Review

\title{
Strategies to promote farm animal welfare in Latin America and their effects on carcass and meat quality traits
}

\author{
Mateus J.R. Paranhos da Costa ${ }^{\text {a,* }}$, Stella M. Huertas ${ }^{\mathrm{b}}$, Carmen Gallo ${ }^{\mathrm{c}}$, Osmar A. Dalla Costa ${ }^{\mathrm{d}}$ \\ a Grupo ETCO, Departamento de Zootecnia, Faculdade de Ciências Agrárias e Veterinárias, UNESP, 14884-900, Jaboticabal-SP, CNPq, Brazil \\ b Facultad de Veterinaria, Universidad de la República, Lasplaces 1550, Montevideo 11600, Uruguay \\ ' Instituto de Ciencia Animal y Tecnología de Carnes, Facultad de Ciencias Veterinarias, Universidad Austral de Chile, Casilla 567, Valdivia, Chile \\ d Embrapa Suínos e Aves, BR153 km 110, CP. 21, 89700-000, Concórdia-SC, Brazil
}

\section{A R T I C L E I N F O}

\section{Article history:}

Received 20 January 2012

Received in revised form 2 March 2012

Accepted 7 March 2012

\section{Keywords:}

Animal handling

Cattle

Education

Transportation

Slaughter

Pigs

\begin{abstract}
A B S T R A C T
Several initiatives, including research and development, increasing stakeholders' awareness and application of legislation and recommendation, have been carried out in Latin America to promote animal welfare and meat quality. Most activities focused on the impact of pre-slaughter conditions (facilities, equipment and handling procedures) on animal welfare and meat quality. The results are encouraging; data from Brazil, Chile and Uruguay showed that the application of the improved pre-slaughter handling practices reduced aggressive handling and the incidence of bruised carcasses at slaughter in cattle and pigs. These outcomes stimulated some to apply animal welfare concepts in livestock handling within the meat production chain as shown by the increasing demand for personnel training on the best. To attend this demand is important to expand local studies on farm animal welfare and to set up (or maintain) an efficient system for knowledge transfer to all stakeholders in the Latin America meat production chains. However, it is clear that to promote the long-term progress in this field is important to deliver practical solutions, assuring that they match the technical and financial conditions of those who are the target of training programs.
\end{abstract}

(c) 2012 Elsevier Ltd. All rights reserved.

\section{Contents}

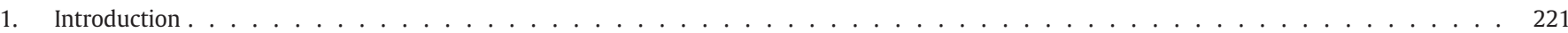

2. Farm animal welfare in Latin America . . . . . . . . . . . . . . . . . . . . . . . . . . . . . . . . . . . . . . . . . . . 222

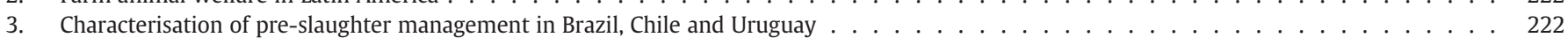

4. Initiatives to promote the welfare of production animals in Latin America . . . . . . . . . . . . . . . . . . . . . . . . . . . . . . . . 223

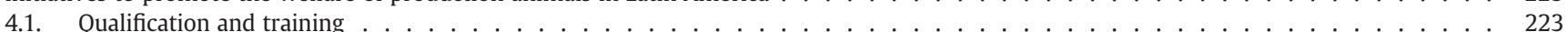

5. Evidence of the positive effects of these initiatives on carcass bruising . . . . . . . . . . . . . . . . . . . . . . . . . . . . 224

6. Conclusions and implications . . . . . . . . . . . . . . . . . . . . . . . . . . . . . . . . . . . . . . . 224

References . . . . . . . . . . . . . . . . . . . . . . . . . . . . . . . . . . . . . . . . . 225

\section{Introduction}

Many factors define meat quality, especially those that determine its intrinsic characteristics (e.g., colour, flavour, tenderness and nutritional value), safety, appearance and convenience (Koohmaraie \& Geesink, 2006). Meat quality can also be defined based on ethical criteria, particularly those related to environmental and animal welfare concerns (Paranhos da Costa, 2004).

\footnotetext{
* Corresponding author at: Rod. Prof. Paulo Donato Castellane, Departamento de Zootecnia, FCAV-UNESP, 14884-900, Jaboticabal-SP, Brazil. Tel./fax: + 551632023430. E-mail address: mpcosta@fcav.unesp.br (M.J.R. Paranhos da Costa).
}

Despite an emphasis on the negative effects of stress during preslaughter management, which result in quantitative and qualitative meat loss (Gallo, 2009; Warriss, 2000), the mechanisms involved in these losses remain unknown (Ferguson \& Warner, 2008), with the exception of situations that cause physical damage to the carcasses or that result in muscle glycogen depletion (Gregory, 2007; Lacourt, 1985; Warriss, 1990). Furthermore, situations arise while conducting pre-slaughter management procedures that result in negative consequences for the welfare of the animals and a high risk of death.

Several studies have been conducted in Latin America to evaluate the impact of stress during pre-slaughter management on the quality of beef and pork, with a focus on handling procedures (Faucitano, 
Marquardt, Oliveira, Coelho, \& Terra, 1998), duration of transportation (Gallo, Lizondo, \& Knowles, 2003; Mota-Rojas et al., 2006), waiting time in slaughterhouse pens (del Campo, Brito, Soares de Lima, Hernández, \& Montossi, 2010), the models of vehicles used for transportation (Dalla Costa et al., 2007; Dalla Costa et al., 2007) and genetic predisposition to stress (Bridi, Rübensam, Nicolaiewsky, Lopes, \& Lobato, 2003). However, we found no studies regarding the negative economic impact resulting from the unethical treatment of animals and its effects on defining the ethical quality of the meat.

Commercial systems that include indirect trade through cattle markets or auctions, prolonged transportation and long waiting times under fasting conditions clearly result in even greater prevalence of carcass bruising, colour problems and unsuitable $\mathrm{pH}$ of the meat. Moreover, the scarce attention given to the suffering of animals during management and stunning in many Latin American countries indicates a high risk of problems with animal welfare and meat quality (Gallo, 2007; Gallo \& Tadich, 2008).

Despite the lack of information, there is growing interest from meat production chains in incorporating certain compromises with sustainable production in their quality control programs and promoting human and animal well being in the pursuit of corporate sustainability.

This article aims to present the initiatives developed in Latin America to promote animal welfare during pre-slaughter management and their effects on carcass and meat quality, with an emphasis on the pre-slaughter management of cattle and swine in Brazil, Chile and Uruguay.

\section{Farm animal welfare in Latin America}

Agriculture comprises a significant proportion of the Latin American economy, with strong performance from the poultry, beef and pork production sectors. For instance, growth rates of agriculture in Brazil have been above average, even during periods of low economic growth (Spolador \& Fontana, 2006). Meat production plays an important role, with an annual production of over 13 million tons of poultry meat and the slaughter of 42.4 million head of cattle and 42.0 million pigs. This production primarily serves the domestic market, which absorbs between 71 and $83 \%$ of the meat produced; the surplus is destined for export (Anualpec, 2011). Although the percentage of exports is relatively low, Brazil has been a world leader in beef (ABIEC, 2009) and poultry (UBABEF, 2010) exportation and still holds a leading position within the pork export market (ABIPECS, 2009).

More than 500 thousand tons of poultry meat is produced annually in Chile, and more than 800 thousand cattle and 5 million pigs are slaughtered per year. Approximately $15.0 \%$ of the poultry meat, $9.6 \%$ of the beef and $18.8 \%$ of the pork produced are exported from this country (INE, 2011).

There is a relevant production and export of beef in Uruguay, which represented $92 \%$ of all meat exports from the country in 2008 (Bonifacino, 2008). Between 2000 and 2006, the country had an average herd of more than 11 million cattle and slaughtered more than two million cattle per year (INAC, 2007). More than $80 \%$ of the meat produced was exported. The pork and poultry industries are very small in Uruguay, in 2009 the country produced only 7.8 thousand tons of poultry meat and 17.3 thousand tons of pork (DIEA, 2010).

The increasing awareness of Latin America livestock stakeholders regarding animal welfare has been mainly achieved by showing the evidence of an association between poor welfare and quantitative and qualitative meat losses. These losses are specifically related to animal deaths, increased bruising of carcasses and changes in the $\mathrm{pH}$ of meat, resulting from the application of poor pre-slaughter management practices.

In parallel, the interest in meeting the requirements of more sensitive markets and the pressure imposed by the need to pass animal welfare audits has also motivated meat production chains to improve their facilities, equipment and management.
Apparently, this ethical approach is still having little practical impact on the human attitude towards animals within the meat production chains.

The poor response of the livestock industry to the animal welfare recommendations can be partly explained by the relatively recent (only 10 years) implementation of these initiatives which were joined with changes in the legislation and the development and application of animal handling training programs.

\section{Characterisation of pre-slaughter management in Brazil, Chile and Uruguay}

A number of surveys run in Uruguay and Brazil have shown the inadequacy of handling practices at various stages of the pre-slaughter handling resulting in the occurrence of severe carcass bruising (Huertas, Gil, Piaggio, \& van Eerdenburg, 2010; Paranhos da Costa, Zuin, \& Piovesan, 1998).

One of these surveys was conducted in Brazil in 1997 by Paranhos da Costa et al. (1998) to assess pre-slaughter management in the beef quality control program of the Fund for the Development of Livestock in the State of São Paulo (Fundo para o Desenvolvimento da Pecuária no Estado de São Paulo - Fundepec) by tracking the entire preslaughter management of 216 animals from loading at the farm to stunning at the slaughterhouse. Cattle showed signs of stress despite the good transportation conditions (new trucks and good roads) and short journeys (no more than $300 \mathrm{~km}$ ), and approximately $50 \%$ of the carcasses had at least one bruise. Based on this survey, the authors identified the following five main problems that increase the risk of carcass bruising during pre-slaughter management in order of significance: 1) direct aggression, 2) high social density, especially in farm corrals and loading docks, 3) inadequate facilities, 4) inadequate transportation (characterised by poor road conditions and poorly maintained vehicles) and 5) severe agitation of the cattle as the result of aggressive management and their high reactivity.

More recent surveys conducted in Brazil indicate even higher percentages of bruised carcasses, reaching $84.2 \%$ in a study conducted in the Pantanal region of Mato Grosso do Sul (Andrade et al., 2008) and $92.1 \%$ in the State of Minas Gerais (Andrade \& Coelho, 2010). These results are certainly due to poor transportation and handling conditions.

The occurrence of carcass bruising can also be caused by poor conditions at the farm. In a study conducted in the State of Santa Catarina (southern Brazil) on pigs, Dalla Costa et al. (2009) reported that 53.7\% of pigs already presented skin lesions at the farm, before loading. This proportion further increased through the marketing process from 80.7 (after loading) to $95.8 \%$ (in lairage at the slaughter plant). Some of these injuries were associated with management procedures, including the position of the animal inside the loading compartment and the duration of pre-slaughter fasting.

The incidence of PSE (pale, soft and exudative) pork is still high in Brazil, e.g. Maganhini et al. (2007) working with 946 Dalland ${ }^{\circledR}$ pigs reported $22.8 \%$ of PSE pork and Culau, López, Rubensam, Lopes, and Nicolaiewsky (2002) working with commercial hybrids (resulting from crossing Landrace, Large White and Duroc) found PSE pork in $36.56,58.53$ and $85.71 \%$ of the pigs according to the halothane gene (HAL) presence (for $\mathrm{HAL}^{\mathrm{NN}}, \mathrm{HAL}^{\mathrm{Nn}}$ and $\mathrm{HAL}^{\mathrm{nn}}$ pigs, respectively). The high occurrence of PSE pork in Brazil was attributed by the first authors to poor pre-slaughter handling conditions. However, the genetic component of the animals should also be considered, since the occurrence of HAL was still high in Brazilian pig herds, 38.41\% according to Culau et al. (2002).

In the late 90s, Faucitano et al. (1998) ran a pioneer study in Brazil aiming at comparing the effects of two pre-slaughter handling procedures on pork quality. The handling procedures under study consisted of either: a) driving pigs to slaughter using electric prods, low-voltage $(110 \mathrm{~V})$ electrical stunning, delayed stick-stun time (15 s) and exsanguination after hanging on the bleeding rail (control); or b) no electric 
prodding, high-voltage (220 V) electric stunning and exsanguination within $15 \mathrm{~s}$ in the prone position (improved procedure). The improved handling procedure resulted in a lower carcass blemish score (LSM \pm SE: $0.9 \pm 0.8$ and $1.8 \pm 1.04, P<0.05)$, a lower number of PSE carcasses $(\mathrm{pH} \mathrm{LSM} \pm \mathrm{SE}$ : Longissimus thoracis $5.6 \pm 0.21$ and $5.9 \pm 0.28$ and Semimembranosus muscles $5.7 \pm 0.18$ and $6.2 \pm 0.22, P<0.01$ for both respectively) and lower concentration of creatine phosphokinase ( $\mathrm{LSM} \pm \mathrm{SE}$ : $3.4 \pm 0.16$ and $3.5 \pm 0.23 \log \mathrm{UI} / \mathrm{l}, P<0.01$, respectively) than the control procedures.

A series of studies comparing two stunning methods (manual electric stunning vs. collective gaseous system) was carried out in Brazil in three pigs genetic strains (defined as A, B and C), assessing: blood stress indicators, objective measures of carcass and meat quality and subjective measures of carcass and meat quality. The results from these papers showed that the animals stunned with the gaseous stunning system presented results for the following indicators of animal welfare and carcass and meat quality: plasmatic levels of cortisol and lactate (Bertoloni, Silveira, Ludtke, \& Andrade, 2006); b* value, $\mathrm{pH} 24 \mathrm{~h}$ in the semimembranosus muscle, light scattering (Hennessy-GP4) to $45 \mathrm{~min}$ and $24 \mathrm{~h}$ post mortem (Bertoloni, Silveira, Ludtke, \& Costa, 2006); and bloodsplash, skin damage and eyelid reflex levels (Bertoloni, Silveira, Costa, \& Ludtke, 2006) than the electric stunning system. The authors reported variation among the genetic strains for some of indicators evaluated, suggesting the occurrence of genotype-environment interactions for those traits.

A study conducted in Uruguay (Huertas et al., 2010) found that $60 \%$ of the total number of beef carcasses assessed $(N=15,168)$ had at least one traumatic lesion; among the bruised carcasses 33\% had one bruise, $25 \%$ two bruises, $16 \%$ three bruises and $26 \%$ had four or more bruises. Data collected in a beef and lamb quality audit in Uruguay (INIA (Instituto Nacional de Investigación Agropecuaria), INAC (Instituto Nacional de Carnes), \& Colorado State University, 2003 ) also indicated high occurrences of bruises in cattle (60\%) and sheep (30\%) carcasses. The authors reported that carcass bruising was associated with the following pre-slaughter factors: truck maintenance (with higher occurrence of bruises in not well maintained trucks), presence of side reels on the doors of the loading compartment (that reduced bruised carcasses) and travel conditions (increasing the number of bruised carcass when the transport was done in poor road conditions). The presence of bruises on the carcasses resulted in an average removal of $2 \mathrm{~kg}$ of meat per lesion per animal (Huertas et al., 2010), which represents a great economic loss for the beef production chain.

Surveys on the incidence of carcass bruising in cattle slaughtered in Chile, carried out by the official certification of meat quality in the slaughterhouses, indicated lower frequencies than those obtained in Brazil and Uruguay, with values ranging from 7.7 to 20.7\% (Gallo, Caro, Villarroel, \& Araya, 1999; Strappini, Frankena, Metz, Gallo, \& Kemp, 2010; Strappini, Sandoval, Gil, Silva, \& Gallo, 2008). However, when the prevalence of bruising was assessed in cows (the cattle category that presented the highest frequency of bruises, according to Strappini et al. (2010)), the prevalence of bruising was much higher $(92.2 \%)$ than the previous figures (Strappini, Frankena, Metz, Gallo, \& Kemp, 2012). The authors identified a higher percentage of carcasses free of bruises when they were sourced directly from farms than those that were sourced from livestock markets $(13 / 111,11.7 \%$ and $7 / 147,4.8 \%$, respectively; the Fisher exact $P=0.058$ ).

The stunning and slaughter procedures applied in the three countries have been also reported to have a negative impact on animal welfare and carcass quality; depending on the stunning method or the design of the equipment used. There was no indication of effects of these conditions on meat quality in the cited studies.

In a comparative study (Bertoloni \& Andreola, 2010) between two types of stunning boxes, either a conventional model (without any restraint device) or an improved model (with a head restraint devices); using the same pneumatic gun with compressed air in both, the authors recorded a higher first-shot stunning efficiency in the box operated with restraint devices ( 94 vs. $84 \%$ ).

The first animal welfare audit in Uruguay was conducted in 2003 and assessed 17 slaughterhouses authorised for export. The methodology used in this audit was described by Grandin (1998), including the evaluation of animal conditions and management performed at the slaughterhouses, from the guiding of animals into the pens to stunning. At that time, most of the plants evaluated demonstrated deficiencies in the evaluated criteria: loss of consciousness did not occur with the first blow in 13 of the slaughterhouses, the occurrence of vocalisation exceeded acceptable levels at all slaughterhouses, the use of electric prods was above maximum limits in 12 slaughterhouses and the percentage of falls and slips exceeded the maximum acceptable limits in 11 slaughterhouses (Imelio, Ibarlucea, \& Borca, 2011). The second audit conducted in the beef and lamb production chains (INIA, \& INAC, 2009) in Uruguay evidenced a significant reduction in the percentage of cattle carcasses with bruises, decreasing from 60 to 32\% over the four years between the two audits.

\section{Initiatives to promote the welfare of production animals in Latin America}

Several initiatives (technical, legislative and political) have been developed in Latin America in an attempt to promote the welfare of livestock, with an emphasis on capacity building programs and the production of best management practices guidelines.

\subsection{Qualification and training}

In Chile, a program for the evaluation of pre-slaughter management conditions of cattle based on the method described by Grandin (1998) and slaughterhouse staff training was initiated in 2003. The first step was to perform an assessment of the management conditions of the slaughterhouse, followed by training in animal welfare and best management practices of handling and, concluded with a new assessment of handling practices using the trained personnel (using the same indicators as those used in the initial assessment). The results revealed a significant improvement in management conditions, with a $47.7 \%$ reduction in the use of electric prods during management (Gallo, Altamirano, \& Uribe, 2003), better first-shot stunning efficiency (from 72.8 to $97.8 \%$ ) and an increased percentage of animals correctly stunned from 0.0 to $99.8 \%$ (Gallo, Teuber, Cartes, Uribe, \& Grandin, 2003).

Another staff training project (Gallo, 2010) run at 15 cattle and sheep slaughter plants between 2005 and 2010 resulted in a reduced incidence ( 4.5 to $0.5 \%$ ) of animals showing signs of consciousness after stunning. Although the target of a maximum of $0.2 \%$ conscious animals was not achieved, this study showed the usefulness of personnel training to improve animal welfare at slaughter.

In Uruguay, training programs and distribution of guidelines through the cattle production chain and academic community were performed by the School of Veterinary Medicine at the University of the Republic in collaboration with the Collaborating Centre of the International Organization of Epizootics (OIE). The results of these initiatives have been recognised in the animal welfare audit conducted by the National Institute of Agricultural Research (Instituto Nacional de Investigaciones Agrícolas - INIA) and the National Institute of Meat (Instituto Nacional de Carnes - INAC) in 2008 (INIA, \& INAC, 2009), as reported previously in this article.

The development of best management practice guidelines, including detailed information on the best way to conduct the various management procedures involved in the performance of a given process, has been developed by Group ETCO (Ethology and Animal Ecology Research Group) at São Paulo State University (Universidade do Estado de São Paulo - UNESP). The adopted strategy was for each guideline's title to address a specific process defined based on the 




Fig. 1. Percentage of carcasses downgraded due to severe bruising as a result of adopting a training program on best animal welfare practices and the supervision of preslaughter management procedures. Carrefour Guarantee of Origin program in the State of Mato Grosso do Sul, Brazil. (Adapted from Paranhos da Costa, 2004).

routine management of farms and slaughterhouses; for instance, two guidelines were developed concerning cattle loading (Paranhos da Costa, Quintiliano, \& Spironelli, 2008) and transportation processes (Paranhos da Costa, Quitiliano, \& Tseimazides, 2010), offering recommendations for how to perform these management tasks. The resulting guidelines are distributed free of charge, in online (www. grupoetco.org.br) and printed versions.

Booklets for disseminating best practices in cattle management that provide guidelines for procedures implemented in farms, during transportation and in slaughterhouses have also been developed in Uruguay and Chile. The materials are available at www.bienestaranimal. org.uy and www.bienestaranimal.cl.

More detailed information on animal welfare education in Latin America is presented by Gallo et al. (2010).

\section{Evidence of the positive effects of these initiatives on carcass bruising}

Most records show the effects of animal welfare initiatives on a reduction in carcass bruising in cattle and pigs.

The work developed within the Carrefour ${ }^{\circledR}$ Guarantee of Origin (GO) Program in partnership with Group ETCO (UNESP) is an example of the involvement of various links in the beef production chain in favour of animal welfare and meat quality. The GO program is an international initiative of the Carrefour ${ }^{\circledR}$ supermarket chain, whose

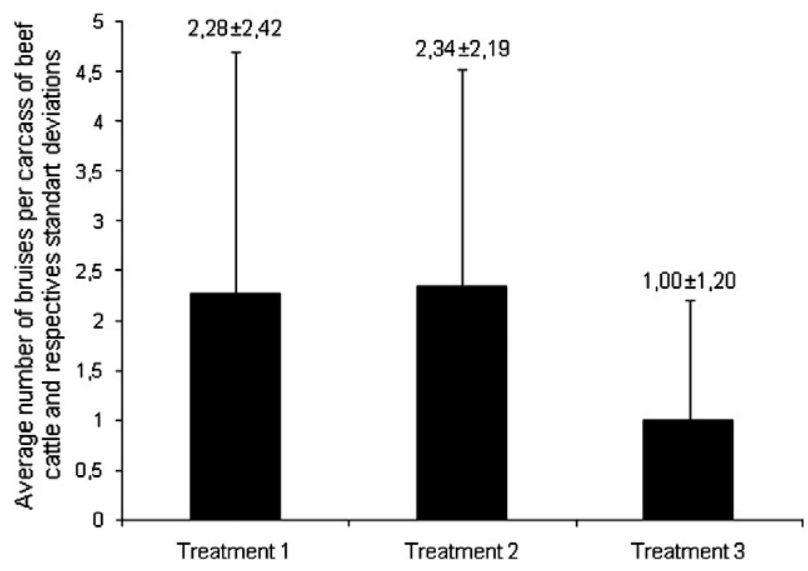

Fig. 2. Means and standard deviations of bruising per carcass of beef cattle according to the type of management adopted for cattle loading at a farm in the State of São Paulo, Brazil. (Adapted from Paranhos da Costa et al., 2008). T1 = routine farm management; $\mathrm{T} 2=$ routine farm management, eliminating the use of electric prods; and $\mathrm{T} 3=$ implementation of best management practices, involving the adoption of best management practices for forming lots and loading. objective is to produce animal welfare friendly and high quality meat (Carrefour, 2012). With the objective to reduce downgrading of beef carcass due to bruising, a training program involving the staff of 120 farms was run in Mato Grosso do Sul between June 2000 and April 2001.

As shown in Fig. 1 the implementation of the training program resulted in a significant reduction in the proportion of downgraded carcass due to bruising. The efficiency of the GO training program has been largely acknowledged through the media. However, negative emphasis is given to the increased percentage of carcasses downgraded due to severe bruising six months after the end of the training program, which demonstrates the need to maintain a constant follow-up of the pre-slaughter management procedures to ensure that the advances obtained are maintained over time.

Other personnel training initiatives to improve livestock welfare in Brazil are represented by the truck drivers training program, delivered by Embrapa Suínos e Aves, with the participation of 250 drivers in 2010, and STEPS program (National Program on Humane Slaughter) that trained from August 2009 to December 2010 more than 1500 professionals in 217 slaughter plants (WSPA, 2011).

The activity of several research groups in Brazil and Uruguay also contributed to the improvement of handling practices aiming at reducing carcass bruising in cattle. In Brazil, based on the results of a survey of carcass bruising on 600 beef cattle originating from a farm in the state of São Paulo which showed an average of $2.35 \pm 2.12$ bruises per carcass (ranging from 0 to 12 bruises/carcass), an experiment was carried out with the objective to identify the contribution of the handling procedures at loading on this carcass defect (Paranhos da Costa et al., 2008). Three handling procedures were compared in this study: $\mathrm{T} 1=$ routine farm management; $\mathrm{T} 2=$ routine farm management, eliminating the use of electric prods and T3 = adoption of best management practices, which involved improvements in the handling procedures, eliminating shouting and aggressive handling (hitting and electric prodding cattle) when preparing cattle batches for loading and running the loading procedures. The application of the improved practice (T3) resulted in a $56.9 \%$ reduction in carcass bruising (Fig. 2).

\section{Conclusions and implications}

It is worth noting that it is relatively simple to recognise and correct problems with animal welfare when the situation is critical; however, it becomes increasingly difficult to improve welfare once the most obvious problems are resolved (Paranhos da Costa \& Pinto, 2006). Therefore, the process is one of continuous improvement, and the complexity of the problems encountered increases with every advance achieved. The working conditions and procedures performed should be periodically reviewed to maintain the advances achieved and to provide opportunities for further improvement.

We understand that to promote the long-term adoption of best management practices in Latin America, it will be necessary to provide solutions to the problems faced in everyday work at the farms and slaughterhouses and to guide all those involved in how to implement them. Thus, a change in focus is necessary, from discussing "what is going wrong" to addressing "how to solve the problem" (Quintiliano \& Paranhos da Costa, 2008). It is worth noting that the solutions to the problems of animal welfare during pre-slaughter management in Latin America should be simple and easy to apply and should be matched to the technical and financial conditions of those who intend to apply them, with evidence of a greater chance for success when the well-being of the workers is also considered.

The successful experiences of raising awareness and training in animal welfare and best management practices should be repeated in many other parts of Latin America that face similar problems. It is also necessary to broaden the studies that address farm animal 
welfare and to maintain an efficient system for the transfer of knowledge to all participants in the meat production chain.

Only then will it be possible to sustain the advances achieved and to broaden the positive actions that result to provide conditions for expanding the progress made with the improvement of farm animal welfare in Latin America, responding to the increasing demand of internal and external markets for products with high standard of animal welfare.

\section{References}

ABIEC (Associação Brasileira das Indústrias Exportadoras de Carnes) (2009). Brasil lidera ranking de exportação de carne bovina. Retrieved from http://www.abiec.com.br/ news_view.asp?id=\%7BCAACE975-B5D1-4337-9F3B-580E7118CB45\%7D (January 5th, 2012).

ABIPECS (Associação Brasileira da Indústria Produtora e Exportadora de Carne Suína) (2009). Exportação mundial de carne suína. Retrieved from http://www.abipecs. org.br/index.php?page =exportacao (January 5th, 2012).

Andrade, J., \& Coelho, H. E. (2010). Ocorrência de contusões em carcaças bovinas e suas per das econômicas. Cadernos de Pós-Graduação da FAZU (pp. 1). Retrieved from http:/ www.fazu.br/ojs/index.php/posfazu/article/viewFile/332/238 (January 5th, 2012).

Andrade, E. N., Silva, R. A. M. S., Roça, R. O., Silva, L. A. C., Gonçalves, H. C., \& Pinheiro, R. S. B. (2008). Ocorrência de lesões em carcaças de bovinos de corte no Pantanal em função do transporte. Ciência Rural, 38(7), 1991-1996.

Anualpec (2011). Anuário da pecuária brasileira. São Paulo: Instituto FNP.

Bertoloni, W., \& Andreola, D. (2010). Eficácia do sistema de contenção (automatizado mecânico) no atordoamento de bovinos. Ciência Rural, 40(8), 1821-1827.

Bertoloni, W., Silveira, E. T. F., Costa, M. R., \& Ludtke, C. B. (2006). Avaliação de diferentes híbridos suínos submetidos à insensibilização elétrica e gasosa $\left(\mathrm{CO}_{2}\right)$. Parte 3 Mensurações visuais de qualidade. Ciência e Tecnologia de Alimentos, 26(2), 343-351.

Bertoloni, W., Silveira, E. T. F., Ludtke, C. B., \& Andrade, J. C. (2006). Avaliação de diferentes híbridos suínos submetidos à insensibilização elétrica e gasosa $\left(\mathrm{CO}_{2}\right)$. Parte 1 -Mensuração de indicadores sanguíneos de estresse. Ciência e Tecnologia de Alimentos, 26(3), 564-570.

Bertoloni, W., Silveira, E. T. F., Ludtke, C., \& Costa (2006). Avaliação de diferentes híbridos suínos submetidos à insensibilização elétrica e gasosa $\left(\mathrm{CO}_{2}\right)$. Parte 2 Mensurações objetivas de qualidade. Ciência e Tecnologia de Alimentos, 26(3), 555-563.

Bonifacino, L. (2008). Exportaciones de carne de Uruguay. Retrieved from http:/ www.engormix.com/MA-ganaderia-carne/frigorifico/articulos/exportacionescarne-uruguay-t2040/378-p0.htm (January 4th, 2012).

Bridi, A. M., Rübensam, J. M., Nicolaiewsky, S., Lopes, R. F. F., \& Lobato, J. F. (2003). Efeito do genótipo halotano e de diferentes sistemas de produção na qualidade da carne suína. Revista Brasileira de Zootecnia, 32(6), 1362-1370.

Carrefour (2012). Carne bovina: O produtor garantia de origem. Retrieved from http:// www.garantiadeorigem.com.br/Produtos/Certificados/ (January 9th, 2012).

Culau, P. O. V. A., López, J., Rubensam, J. M., Lopes, R. F. F., \& Nicolaiewsky, S. (2002). Influência do gene halotano sobre a qualidade da carne suína. Revista Brasileira de Zootecnia, 31(2), 954-961.

Dalla Costa, O. A., Faucitano, L., Coldebella, A., Ludke, J. V., Peloso, J. V., Dalla Roza, D. et al. (2007). Effects of the season of the year, truck type and location on truck on skin bruises and meat quality in pigs. Livestock Science, 107(1), 29-36.

Dalla Costa, O. A. Ludke, J. V., Paranhos da Costa, M. J. R., Faucitano, L., Peloso, J. V., \& Dalla Roza, D. (2007). Modelo de carroceria e seu impacto sobre o bem-estar e qualidade da carne dos suínos. Ciência Rural, 37(5), 1418-1422.

Dalla Costa, O. A., Ludke, J. V., Paranhos da Costa, M. J. R., Faucitano, L., Peloso, J. V., Dalla Roza, D., et al. (2009). Efeito do jejum na granja e condições de transporte sobre o comportamento dos suínos de abate nas baias de descanso e lesões na pele. Ciência Animal Brasileira, 10(1), 58-68.

del Campo, M., Brito, G., Soares de Lima, J., Hernández, P., \& Montossi, F. (2010). Finishing diet, temperament and lairage time effects on carcass an meat quality traits in steers. Meat Science, 86, 908-914.

DIEA (Oficina de Estadísticas Agropecuarias del Ministerio de Ganadería, Agricultura y Pesca) (2010). Anuario Estadístico Agropecuario 2010. Retrieved from http://www. mgap.gub.uy/Dieaanterior/Anuario2010/DIEA-Anuario-2010w.pdf (February 27th, 2012).

Faucitano, L., Marquardt, L., Oliveira, M. S., Coelho, H. S., \& Terra, N. N. (1998). The effect of two handling and slaughter systems on skin damage, meat acidification and colour in pigs. Meat Science, 50(1), 13-19.

Ferguson, D. M., \& Warner, R. D. (2008). Have we underestimated the impact of preslaughter stress on meat quality in ruminants? Meat Science, 80, 12-19.

Gallo, C. (2007). Animal welfare in the Americas. Proceedings of the 18th Conference of the OIE Regional Commission for the Americas. Compendium of Technical Items presented to the International Committee or to the Regional Commissions of the OIE. Florianópolis, Brasil. (pp. 151-166).

Gallo, C. (2009). Bienestar animal y buenas prácticas de manejo animal relacionadas con la calidad de la carne. In G. Bianchi, \& O. Feed (Eds.), Introducción a la ciencia de la carne (pp. 455-494). Montevideo, Uruguay: Editorial Hemisferio Sur.

Gallo, C. (2010). (FIA-PI-C-2005-1-P-010) Diagnóstico e implementación de estrategias de bienestar animal para incrementar la calidad de la carne de rumiantes, financiado por la Fundación para la Innovación Agraria (FIA-Chile) y la Asociación Gremial de Plantas Faenadoras y Frigoríficos de Carne (FAENACAR-Chile), 2005-2010.].
Gallo, C., Altamirano, A., \& Uribe, H. (2003). Evaluación del bienestar animal durante el manejo de bovinos previo al faenamiento en una planta faenadora de carnes. Libro de Resumenes VI Jornadas Chilenas de Buiatría. Pucón, Chile (pp. 107-108).

Gallo, C., Caro, M., Villarroel, C., \& Araya, P. (1999). Características de bovinos faenados en la Xa Región (Chile) según las pautas indicadas en las normas oficiales de clasificación y tipificación. Archivos de Medicina Veterinaria, 31, 81-88.

Gallo, C., Lizondo, G., \& Knowles, T. G. (2003). Effects of journey and lairage time on steers transported to slaughter in Chile. Veterinary Record, 152, 361-364.

Gallo, C., \& Tadich, T. A. (2008). South America. In M. C. Appleby, V. Cussen, L. Garcés, L. Lambert, \& J. Turner (Eds.), Long distance transport and welfare of farm animals (pp. 261-287). Wallinford-UK: CABI Publishing.

Gallo, C., Tadich, T., Huertas, S., César, D., Paranhos Da Costa, M. J. R., \& Broom, D. M. (2010). Animal welfare education in Latin América. Proceedings of the First International Conference on Animal Welfare Education: Everyone is responsible. Brussels, Belgium (pp. 90-97).

Gallo, C., Teuber, C., Cartes, M., Uribe, H., \& Grandin, T. (2003). Mejoras en la insensibilización de bovinos con pistola neumática de proyectil retenido tras cambios de equipamiento y capacitación del personal. Archivos de Medicina Veterinaria, 35(2), 159-170.

Grandin, T. (1998). Objective scoring of animal handling and stunning practices at slaughter plants. Journal of the American Veterinary Medical Association, 212, 36-39.

Gregory, N. (2007). Animal welfare and meat production. (2nd ed). Wallingford-UK: CABI Publishing Chapter 12

Huertas, S. M., Gil, A. D., Piaggio, J. M., \& van Eerdenburg, F. J. C. M. (2010). Transportation of beef cattle to slaughterhouses and how this relates to animal welfare and carcass bruising in an extensive production system. Animal Welfare, 19, 281-285.

Imelio, J. J., Ibarlucea, A., \& Borca, A. (2011). 2da Auditoría de Bienestar Animal en la Industria Frigorífica del Uruguay (2009-2010). Revista Carnes y Alimentos, 37, 14-21.

INAC (Instituto Nacional de Carnes) (2007). 30 años de información 1977-2006. Retrieved from http://www.inac.gub.uy/innovaportal/file/1061/1/30_de_info.pdf (January 4th, 2012)

INE (Instituto Nacional de Estadísticas) (2011). Producción pecuaria: Informe anual 2005-2010. Retrieved from http://www.ine.cl/canales/menu/publicaciones/ calendario_de_publicaciones/pdf/200511/pecu_10180511.pdf (January 10th, 2012).

INIA (Instituto Nacional de Investigación Agropecuaria), \& INAC (Instituto Nacional de Carnes) (2009). 2da Auditoría de Calidad de la Cadena Cárnica Vacuna del Uruguay: 2007 - 2008. Retrieved from http://www.inac.gub.uy/innovaportal/file/3001/1/ auditoria_bovina_2009_web.pdf (January 6th, 2012).

INIA (Instituto Nacional de Investigación Agropecuaria), INAC (Instituto Nacional de Carnes), \& Colorado State University (2003). Auditoría de la Calidad de la Carne Vacuna: Año 2003. Retrieved from http://www.inac.gub.uy/innovaportal/file/3015/ 1/cartilla_vacuna_2003_vers_final.pdf (January 6th, 2012).

Koohmaraie, M., \& Geesink, G. H. (2006). Contribution of postmortem muscle biochemistry to the delivery of consistent meat quality with particular focus on the calpain system. Meat Science, 74, 34-43.

Lacourt, A. (1985). Glycogen depletion patterns in myofibres of cattle during stress. Meat Science, 15, 85-100.

Maganhini, M. B., Mariano, B., Soares, A. L., Guarnieri, P. D., Shimokomaki, M., \& Ida, E. I. (2007). Carnes PSE (Pale, Soft, Exudative) e DFD (Dark, Firm, Dry) em lombo suíno numa linha de abate industrial. Ciência e Tecnologia de Alimentos, 27(1), 69-72.

Mota-Rojas, D., Becerril, M., Lemus, C., Sánchez, P., González, M., Olmos, S. A., et al. (2006). Effects of mid-summer transport duration on pré- and post-slaughter performance of pork quality in México. Meat Science, 73, 404-412.

Paranhos da Costa, M. J. R. (2004). Comportamento e bem-estar de bovinos e suas relações com a produção de qualidade. Anais dos Simpósios da 41a Reunião da Sociedade Brasileira de Zootecnia. Campo Grande, Brasil (pp. 260-268).

Paranhos da Costa, M. J. R., \& Pinto, A. A. (2006). Bem-estar animal: conceitos e implicacões práticas. In E. A. B. Rivera, M. H. Amaral, \& V. P. do Nascimento (Eds.), Ética e bioética aplicadas à medicina veterinária (pp. 107-130). GoiâniaGO: Editora da UFC.

Paranhos da Costa, M. J. R., Quintiliano, M. H., \& Spironelli, A. L. G. (2008). Boas práticas de manejo: Embarque. Jaboticabal: Funep 35 p.

Paranhos da Costa, M. J. R., Quitiliano, M. H., \& Tseimazides, S. P. (2010). Boas práticas de manejo: Transporte. Jaboticabal-SP: Funep $56 \mathrm{p}$.

Paranhos da Costa, M. J. R., Zuin, L. F. S., \& Piovesan, U. (1998). Avaliação preliminar do manejo pré-abate de bovinos do programa de qualidade de carne bovina do Fundepec. : Relatório Técnico $21 \mathrm{pp}$.

Quintiliano, M. H., \& Paranhos da Costa, M. J. R. (2008). The application of driving and stunning techniques in South America - Practical experiences of good handling practices in Brazil. Proceedings of the Conference on Animal Welfare at Slaughter and Killing for Disease Control: Emerging Issues and Good Examples. Skara, Sweden.

Spolador, H. F. S., \& Fontana, F. C. (2006). Exportações do agronegócio e a valorização cambial. Retrieved from: http://www.cepea.esalq.usp.br/pdf/Cepea artigo macro1.pdf. (January 5th, 2012)

Strappini, A. C., Frankena, K., Metz, J. H. M., Gallo, B., \& Kemp, B. (2010). Prevalence and risk factors for bruises in Chilean bovine carcasses. Meat Science, 86, 859-864.

Strappini, A. C., Frankena, K., Metz, J. H. M., Gallo, C., \& Kemp, B. (2012). Characteristics of bruises in carcasses of cows sourced from farms or from livestock markets. Animal, 6(3), 502-509.

Strappini, A. C., Sandoval, M. L., Gil, H., Silva, R., \& Gallo, C. (2008). Utilización de un nuevo protocolo de evaluación de contusiones en canales bovinas. Libro de Resumenes XXXIII Congreso de la Sociedad Chilena de Producción Animal. Valdivia, Chile (pp. 245-246). 
UBABEF (União Brasileira de Avicultura) (2010). Avicultura brasileira em 2010: Exportações e produção. Retrieved from http://www.abef.com.br/noticias_portal/down.php? arq=RXNOYXRpc3RpY2FzX1ViYWJIZl8yMDEwX0ZpbmFsLmRvYw = = (January 5th, 2012).

Warriss, P. D. (1990). The handling of cattle pre-slaughter and its effects on carcass and meat quality. Applied Animal Behaviour Science, 28, 171-186.
Warriss, P. D. (2000). Meat science: An introductory text. Wallingford-UK: CABI Publishing Chapter 7

WSPA (World Society for the Protection of Animals) (2011). Steps: um programa em expansão pelo bem-estar dos animais de produção. Retrieved from: http://www. wspabrasil.org/latestnews/2011/Steps-um-programa-em-expansao-pelo-bemestar-dos-animais-de-producao.aspx (January 7th, 2012). 